\title{
EXCRETION-SECRETION PRODUCTS AND PROTEASES FROM LIVE Sporothrix schenckii YEAST PHASE. IMMUNOLOGICAL DETECTION AND CLEAVAGE OF HUMAN IgG
}

\author{
Daniel DA ROSA(1), Elbio GEZUELE(1), Luis CALEGARI(1) \& Fernando GOÑI(2,3)
}

\begin{abstract}
SUMMARY
Antigenic preparations from Sporothrix schenckii usually involve materials from mixed cultures of yeast and mycelia presenting cross-reactions with other deep mycoses. We have standardized pure yeast phase with high viability of the cells suitable to obtain specific excretion-secretion products without somatic contaminations. These excretion-secretion products were highly immunogenic and did not produce noticeable cross-reactions in either double immunodiffusion or Western blot. The antigenic preparation consists mainly of proteins with molecular weights between 40 and $70 \mathrm{kDa}$, some of them with proteolytic activity in mild acidic conditions. We also observed cathepsin-like activity at two days of culture and chymotrypsin-like activity at four days of culture consistent with the change in concentration of different secreted proteins. The proteases were able to cleave different subclasses of human IgG suggesting a sequential production of antigens and molecules that could interact and interfere with the immune response of the host.
\end{abstract}

KEYWORDS: Sporothrix schenckii; Excretion-secretion product; Human immunoglobulin; Proteases; Yeast phase.

\section{INTRODUCTION}

Sporotrichosis, caused by the dimorphic fungus Sporothrix schenckii (Ss), is a dermo-hypodermic mycosis exceptionally systemic, manifested as a granulomatous chronic infection. Of worldwide distribution its frequency varies among different countries ${ }^{15}$. Because of the saprophytic association of Ss and plants, the fungus entry into the body usually occurs through trauma or scratches produced by thorns, splinters or even contaminated tree bark and timber. Recently, a widespread transmission among cats and to humans in Rio de Janeiro, Brazil, has been described ${ }^{27}$. However, in Uruguay its transmission is predominantly tied to the hunt of the armadillo (Dasypus hybridus) particularity that shares with the northeast of Argentina ${ }^{9,15,26}$.

Visible skin lesions are characteristic of the acute disease; whereas, the subsequent path to chronicity, that involves migration through the lymphatic system and interaction with the host immune defenses, is less defined and not clearly understood. It has been established that cell mediated immunity involving macrophages, monocytes and neutrophils could play an important role in the host immune defense; while the presence of specific antibodies does not provide protection against a subsequent infection ${ }^{15}$.

A murine model of disseminated sporotrichosis obtained by inoculating animals with Ss peptide-polysaccharide antigens has revealed a transient immune depression between the $4^{\text {th }}$ and $6^{\text {th }}$ week after infection?

The yeast phase of Ss produces various antigens, essentially carbohydrates and proteins that could be responsible for such an effect. The most prominent antigen is in the peptide-rhamnomannan fraction expressed in the cell wall glycopeptides components ${ }^{19}$. Using Concanavalin A three main glycoproteins of 84,70 and $58 \mathrm{KDa}$ were identified ${ }^{17}$, its sugar components bind collagen type II, fibronectin and laminin ${ }^{18}$. Other fungi have been shown to produce heat shock proteins (HSP) that could be locally responsible for the effects on the host immune system ${ }^{12,24}$.

Although the antigenic properties of the peptide-rhamnomannan fraction are presently useful for serologic and skin tests, cross- reaction could occur with other deep mycoses ${ }^{19}$. Other studies on predominantly yeast phase have also described a range of antigenic proteins between 22 and $70 \mathrm{KDa}$, including two extra cellular proteinase ${ }^{20}$. The first one named Proteinase I has a chymotrypsin-like behavior and an optimal activity at $\mathrm{pH}$ 6.0. The second one, Proteinase II, has cathepsin-like activity with optimal working activity at $\mathrm{pH} 3.5^{30}$.

In this work, we have focus on the production of pure yeast phase cultures useful to evaluate the time differential appearance of secreted highly specific Ss antigenic proteins with emphasis on proteases that could help in interaction with tissues while interfering with the host immune response.

\section{MATERIALS AND METHODS}

Production of Sporothrix schenckii antigens: To obtain antigens from Sporothrix schenckii (Ss) yeasts we have used the Ss-IH1992 strain. This strain was originally isolated in 1991 at the Mycology Section,

(1) Departamento de Parasitología y Micología, Facultad de Medicina, Universidad de la República, Instituto de Higiene, Avda. A. Navarro 3051 , 11600 Montevideo, Uruguay.

(2) Departamento de Inmunología, Facultad de Química, Universidad de la República, Instituto de Higiene, Avda. A. Navarro 3051 , 11600 Montevideo, Uruguay.

(3) Department of Neurology, New York University, 550 First Ave, New York, NY 10016, USA.

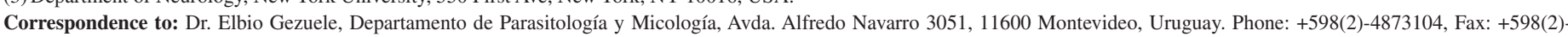
4873073. E-mail: micol@higiene.edu.uy 


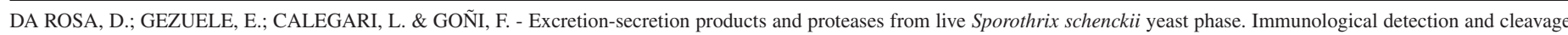
of human IgG. Rev. Inst. Med. trop. S. Paulo, 51(1): 1-7, 2009.

Instituto de Higiene (Montevideo, Uruguay) from a case of a human lymphangitic sporotrichosis. From the many strains obtained from human subjects and available in our laboratory, six were tested, i.e., IH 1992; IH 1993; IH 1994; IH 1995, IH 1463 and IH 2008. Five out of six were obtained in Uruguay but strain IH 2008 which was isolated from a longshoreman infected after a trauma produced with a timber box in Miranda State, Venezuela. The strain was subsequently maintained in Sabouraud/glucose/agar (SGA) (Difco) at $28^{\circ} \mathrm{C}$.

The conversion of the mycelial phase to the yeast phase was obtained after culturing in brain heart infusion-glucose-agar 3.7\% (BHIGA) (Difco). The cultures of Ss mycelial phase fungus with its characteristic filaments and conidia were transferred to BHIGA and cultured at $36.5^{\circ} \mathrm{C}$, $5 \% \mathrm{CO}_{2}$. Every three days the fungus were scrapped and transferred to fresh BHIGA. After every passage the rate of conversion was assessed in the following manner; an aliquot of the culture was placed on a hemocytometer and on each of the five fields yeast were counted on at least twenty squares and the presence of filaments and/or conidiae was noted. A culture was considered as $100 \%$ yeast phase when no filaments of conidia were not seen in any one of the squares, the total yeast count was at least 500 and there were yeasts on every square of the grid. The presence of filaments or conidia in some of the squares accounted for a lesser percentage of the yeast phase on the whole culture.

After the yeast phase was established different antigenic extractions were performed by the following methodologies:

Excretion secretion products obtained from live yeasts (ESPAg LY): Yeasts from 4 day old cultures in BHIGA were collected by gentle scrapping of the culture surface, washed three times in $2 \mathrm{~mL}$ of $0.1 \mathrm{M}$ phosphate- $0.9 \% \mathrm{NaCl} \mathrm{pH} 7.2$ (PBS pH 7.2) centrifuged at 1500xg for five minutes and resuspended in PBS pH 7.2 to a final concentration of $3 \times 10^{8}$ yeasts. The samples with more than $97 \%$ viable yeasts were centrifuged again, the supernatants discarded and only the pellets were kept for immediate use.

Antigens in excretion secretion products derived from live yeasts incubated in short term liquid medium (ESPAg SLM): Yeasts were cultured for seven days in BHIGA $3.7 \%$, at $36.5^{\circ} \mathrm{C}$ and $5 \% \mathrm{CO}_{2}$. Yeasts were collected daily by scrapping, resuspended and washed three times in $2 \mathrm{~mL}$ of PBS pH 7.2, centrifuged at 2000xg for five minutes and the supernatant discarded. The pellets with more than $97 \%$ viable yeasts were resuspended in PBS pH 7.2 (ESPAg-SLM) a final concentration of $2 \times 10^{6}$ yeasts and incubated at $4{ }^{\circ} \mathrm{C}$ for 24 hours.

The samples with viable cells above $95 \%$ were centrifuged at $2000 \mathrm{xg}$ for five minutes and the supernatants aliquoted and stored at $-70{ }^{\circ} \mathrm{C}$ until use.

Somatic antigens (SomAg): The Ss yeasts were cultured for four days in BHIGA, $36.5^{\circ} \mathrm{C}$ and $5 \% \mathrm{CO}_{2}$. Afterwards, the yeasts were collected from the surface of the culture with bacteriological ansa, washed three times in PBS pH 7.2 and centrifuged at $2000 \mathrm{xg}$ for two minutes. The pellets with more than $97 \%$ viable yeasts were resuspended in $2 \mathrm{~mL}$ of PBS pH 7.2 to a final concentration of $2 \times 10^{6}$ yeasts and sonicated (Ultrasonic Processor, Cole-Palmer Instrument Co. Illinois) with 50 bursts of 30 seconds or until no intact yeasts were observed by light microscopy (400x). The sonicated material was centrifuged at 3500xg for five minutes, and the supernatant was aliquoted and stored at $-70{ }^{\circ} \mathrm{C}$ until use.

Viability studies: Aliquots from different yeast preparations were centrifuged at 2000xg and the pellets diluted in a freshly made solution of $1.44 \mathrm{mg} / \mathrm{mL}$ Acridine Orange 1/10 in PBS pH 7.2. The mixture was let stand for 15 minutes at room temperature with occasional mixing and observed by epifluorescence microscopy (Zeiss, NAG2) with excitation lamp of $490 \mathrm{~nm}$ and sweeping filter of $520 \mathrm{~nm}$. The percentage of fluorescent viable yeasts was determined by counting at least 100 yeasts in ten different fields ${ }^{5,13}$.

Rabbit anti-Ss antisera: New Zealand white rabbits were inoculated subcutaneously in four different places in the back and thighs with a $1 \mathrm{mg} / \mathrm{mL}$ solution of proteins from the ESPAg SLM of strain IHM 1992, according to VAITUKAITIS et $a^{32}$.

Serological tests: Double immunodiffusion was used to assess the presence of specific antibodies against antigens of Ss at different stages of the sporotrichosis infection. The human sera used for the assays were obtained at the Clinics of the Mycology Section, Instituto de Higiene, Montevideo, Uruguay. Twenty five sera were from nodular lymphangitic sporotrichosis, five from fixed cutaneous sporotrichosis and three from multiple localization sporotrichosis. The controls for possible cross-reactions were ten sera from histoplasmosis, five from candidiasis, ten from paracoccidioidomycosis, five from leprosy, five from tuberculosis and five from Systemic Lupus Erythematousus. To be used as negative controls fifteen sera from healthy donors from the Public Health Blood Bank were selected; none had detectable antibodies to different mycoses.

As positive controls anti-Ss antibodies were produced in rabbits as above mentioned, and the same technique was used to obtain antibodies in rabbits against whole antigenic extracts from Histoplasma capsulatum (strain IHM 1946), Paracoccidioides brasiliensis (strain Pb 339, CIB, Medellin, Colombia) and Aspergillus fumigatus (strain IH 1513). All produced antisera were aliquoted in $5 \mathrm{~mL}$ sealed flasks and kept at $-20{ }^{\circ} \mathrm{C}$ until use.

Double immunodiffusion test $(D D)$ : Approximately $5 \mathrm{~mL}$ of $1 \%$ melted agarose (Sigma) in $0.05 \mathrm{M}$ Tris- $\mathrm{HCl} \mathrm{pH} 8.6$ were poured onto 5 $\mathrm{cm}$ by $5 \mathrm{~cm}$ Gel-Bond (Pharmacia) slides to obtain a $3 \mathrm{~mm}$ thickness of gel. The pattern for the DD test consisted of a central well surrounded by six wells each of $6 \mathrm{~mm}$ in diameter, according to the method of POLONELLI \& MORACE ${ }^{22,23}$. The plates were stained using $0.15 \%$ Coomassie Brilliant Blue in ethanol: acetic acid: $\mathrm{H}_{2} \mathrm{O}$ 4:2:4 v/v.

Characterization of the Excretion Secretion Products: The protein concentration in all preparations was determined by the bicinchoninic acid method (BCA) in microtiter plates according to the method of REDINBAUGH \& TURLEY ${ }^{25}$. Bovine serum albumin was used as a protein standard.

Polyacrylamide gel electrophoresis (SDS-PAGE) and immunoblotting: SDS-PAGE was performed according to LAEMMLI ${ }^{16}$ in $12.5 \%$ gels. The samples of ESPAg SLM and SomAg for immunoblot were diluted 50\% in sample buffer $(0.07 \mathrm{M}$ Tris-HCl pH 6.8, DTT 0.1M, 2\% SDS and $23 \%$ glycerol), boiled for two minutes, applied onto the gels and run for 


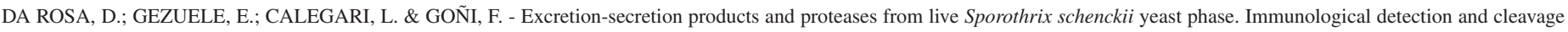
of human IgG. Rev. Inst. Med. trop. S. Paulo, 51(1): 1-7, 2009.

three $\mathrm{h}$ at $20 \mathrm{~mA} / \mathrm{gel}$. After the run the proteins were transferred onto nitrocellulose membranes $(0.45 \mu \mathrm{m}$, Trans-blot, BioRad) using $0.02 \mathrm{M}$ Tris- $0.1 \mathrm{M}$ glycine $\mathrm{pH} 8.3$ overnight at $150 \mathrm{~mA}$ in the semidry-transblot Techware SIGMA, according to TOWBIN et al. ${ }^{29}$.

\section{Determination of protease activity on ESPAg SLM}

Gelatin gels: The ESPAg SLM taken at different days from the cultures were analyzed on $12.5 \%$ polyacrylamide gels containing $0.1 \%$ gelatin as per DALTON \& HEFFERNAN ${ }^{10}$.

Determination of the enzymatic specificity with synthetic fluorogenic substrates: The protease specificity was determined fluorometrically by measuring the release of 7-aminomethylcoumarin (NHMec) (Sigma) from the following peptide substrates coupled to the NHMec: N-succinyl. Ala-Ala-Pro-Phe.AMC, N-succinyl.Leu-Leu-Val-Tyr.AMC, NCBZ GlyGly-Arg.AMC, N-succinyl Gly-Pro-Leu-Gly-Pro.AMC, NCBZ-Phe-Arg. AMC and N-Boc-Val-Leu-Lys.AMC. The different preparations of ESPAg SLM from Ss were used at $1 \mathrm{mg} / \mathrm{mL}$ of protein in $50 \mathrm{mM}$ citrate $\mathrm{pH} 4.5$; the substrate peptides were added to a final $3.6 \mu \mathrm{M}$ concentration in the mixture and incubated at $37^{\circ} \mathrm{C}$ for 60 minutes. The reaction was stopped by the addition of $200 \mu \mathrm{L}$ of $1.7 \mathrm{M}$ acetic acid. The amount of fluorogen released was measured in a Sequoia Turner M 450 fluorometer (Sequoia Turner, Tokyo, Japan) using an excitement lamp of $360 \mathrm{~nm}$ and an emission lamp of $430 \mathrm{~nm}$. One arbitrary unit of enzymatic activity was defined as the amount that catalyzes the release of $1 \mu \mathrm{mol}$ of Mec/ $\mathrm{min} / \mathrm{mg}$ at $37^{\circ} \mathrm{C}^{1}$.

Digestion of human Immunoglobulin subclasses $\operatorname{Ig} G_{1}$ and $\operatorname{Ig} G_{2}$ : Immunoglobulin subclasses $\operatorname{IgG}_{1}$ and $\mathrm{IgG}_{2}$ were purified from human myeloma sera by absorption on a protein $\mathrm{G}$ column (Pharmacia). The purified immunoglobulins were diluted to a final concentration of $1 \mathrm{mg} / \mathrm{mL}$ in the following buffer solutions; $0.1 \mathrm{M}$ citrate $\mathrm{pH} 3.5,0.1 \mathrm{M}$ acetate $\mathrm{pH} 4.5$, $\mathrm{pH} 5.6$ and $0.1 \mathrm{M}$ PBS pH 7.2. The ESPAg SLM were added in a ratio $\mathrm{Ig} / \mathrm{ESPAg}$ of $1: 10 \mathrm{w} / \mathrm{w}$. The mixtures were incubated overnight at $4{ }^{\circ} \mathrm{C}, 27{ }^{\circ} \mathrm{C}$ and $36.5^{\circ} \mathrm{C}$. The reactions were stopped by the addition of a protease inhibitor cocktail to a final concentration of $2 \mathrm{mM}$ PMSF, $10 \mu \mathrm{M}$ E64, $10 \mu \mathrm{M}$ EDTA and $1 \mu \mathrm{M}$ Pepstatin A. As control were used the immunoglobulins and ESPAg SLM separately and those were incubated in equal conditions from the mixtures of digestions. The samples were analyzed on $12.5 \%$ SDS-PAGE and stained with Coomassie Brilliant Blue R 250².

\section{RESULTS}

At least twelve passages were needed to obtain cultures of pure yeasts from transformed Sporothrix schenckii mycelial phase of strain IH 1992 (Fig. 1a). After the yeast phase was established the IH 1992 strain attained logarithmic growth in two days, having a maximum viability of $97 \%$ in the fourth day of culture (Fig.1b). Three other strains: IH 1993, IH 1994, and IH 1995 could not attain either 60\% transformation to yeast phase after more than 15 passages in BHIGA, logarithmic growth after five days of culture and a cell viability of more than $70 \%$ (Fig. 1a)

The two remaining strains, IH 1463 and IH 2008, presented logarithmic growth similar to IH 1992 and attained almost $100 \%$ transformation to yeast phase with $90 \%$ of viable cells after four
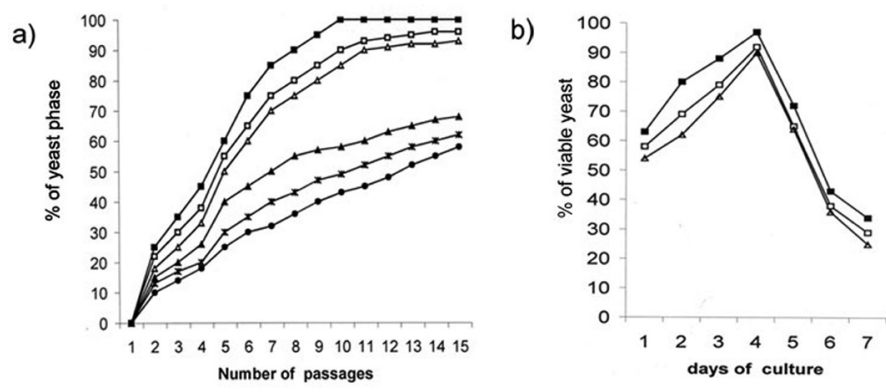

Fig. 1 - a) Conversion in BHIGA of Sporothrix schenckii fungus from mycelial phase to yeast phase expressed as percentage of yeast phase on each passage, see materials and methods. Strains: $\square$ IHM 1992; $\triangle$ IHM 2008; —IHM 1463; A IHM 1995; * IHM 1994; ○ IHM 1993. b) IHM 1992 strain: $\bigcirc$ Percentage of Ss viable yeasts at different days of culture on BHIGA and $\diamond$ protein concentration from the supernatants, determined as $\mu \mathrm{g} / \mathrm{mL}$ (ESPAg SLM).

days in culture. However, the strain IH 1992 showed not only a better transformation and greater cell viability but an unusually high excretion of proteins, $215 \mu \mathrm{g} / \mathrm{mL}$, to the supernatant (Fig. 1b).

Based on these results we choose to continue using the strain IH 1992 and to perform the passages at the fourth day of culture.

\section{Antigenic characterization}

Double immunodiffusion: Based in the greater cell viability and high excretion of proteins of the four days old culture (Fig. 1b), the ESPAgLY and ESPAgSLM were used to prove antibody variability among different manifestations of the disease (Fig. 2). There were a lesser number of precipitation arcs when the sporotrichosis appeared as dermo-hypodermic forms, and that number increased in multilocalized forms with cutaneous dissemination through the lympho-hematic way. No cross-reactions with different mycoses could be observed using live ESPAg LY produced in situ in double immunodiffusion (Fig. 2 III, center well a). The same pattern of precipitation arcs was observed using ESPAg SLM from four days old cultures. However, a preparation of Som Ag showed prominent cross-reactions with Histoplasma capsulatum and Paracoccidioides brasiliensis sera (Fig. 2 III, center well b).

SDS-PAGE, Gelatin-PAGE and Immunoblot: Figure 3 shows that the SomAg from sonicated yeast presents multiple proteic bands in a range between 20 and $90 \mathrm{KDa}$ (Fig. 3a, lane 4); whereas a lesser number of bands were observed for ESPAg SLM (Fig. 3a, lane 2). All ESPAg SLM bands could be ascribed to bands present in the whole yeast but with different relative concentrations (Fig. 3a, lanes 2 and 4). Several bands were recognized in immunoblot by the serum of patients with cutaneous sporotrichosis (Fig. 3a, lane 1). From them, two of the bands, at around 40 and $70 \mathrm{KDa}$, apparent molecular weight. appeared as immunodominant proteic antigens present in different concentrations, in either the SomAg or the ESPAg SLM.

The pure yeast phase of Sporothrix schenckii shed proteic antigens from day one. However, some protein bands changed their relative concentration along the four days of culture. It is noticeable in Fig. 3a, lanes 5 to 8 that whereas the band present around $40 \mathrm{kDa}$ essentially did not change its concentration, the one at around 66-70 kDa increased its presence conversely to the decrease of the 55-58 kDa band. All this 


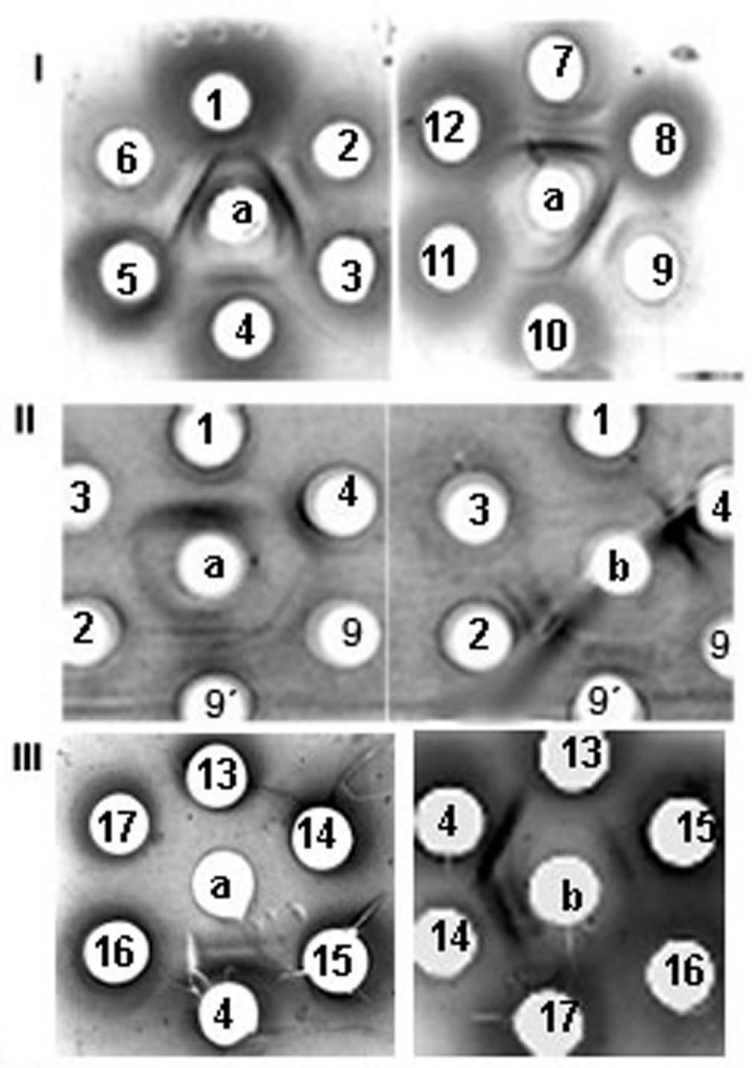

Fig. 2 - Double immunodiffusion with strain IHM 1992 in the center well. Center well a: ExoAg SLY; center well b: SomAg. Numbers 1,8,10: fixed sporotrichosis; 6: lymphocutaneous multiple sporotrichosis; 7: hemato-disseminated sporotrichosis; 2 : rabbit antiserum against Ss ExoAg SLM Ss six weeks after the first injection; 9: rabbit antiserum against Exo Ag SLM two weeks after the first injection; 9' $9^{\prime}$ same as before four weeks after the first injection; 5,11,12, 17: Normal human serum from blood bank healthy donors, tested negative for different mycoses (see M\&M); 3,4: lymphocutaneous sporotrichosis; 13 to 16:human sera from different mycoses; 13: candidiasis; 14: paracoccidioidomycosis; 15: histoplasmosis; 16: aspergillosis. occurred from days one to four of culture when a maximum excretion of proteins maintaining the integrity of the cell - $98 \%$ viability - was shown (Fig. 1b).

The bands at $40 \mathrm{kDa}$ and $70 \mathrm{kDa}$ were also detected in a GelatinPAGE proving them to be proteases present in different amounts at different stages of the yeast development (Fig. 3a, lane 3).

Enzymatic assays with fluorogenic substrates: The results obtained in the Gelatin-PAGE prompted us to determine the type of protease activities present in ESPAg SLM and its fluctuation along the four days period of culture. The comparative hydrolysis of different NH.Mecpeptides by ESPAg SLM of two and four days of culture is presented in Table 1. There is a consistent hydrolysis over time of a N-BocVal-Leu-Lys.AMC, a plasmin-like activity. On the other hand, there is a robust activity at day two of the NCBZ-Phe-Arg.AMC peptide compatible with a cathepsin-like activity that decreases by day four. A similar but lesser effect was seen on an N-Succinyl-Leu-Leu-Val-Tyr. AMC substrate that corroborates the cathepsin activity. After four days it was noticeable an increased activity on the N-Succinyl-Ala-AlaPro-Phe.AMC and N-Succinyl-Gly-Pro-Leu-Gly-Pro.AMC peptides compatible with a chymotrypsin-like activity poorly represented at the first day of culture.

Digestion of IgG subclasses: Because of the cathepsin and chymotrypsin-like activities determined by fluorogenic peptides, the capacity of ESPAg SLM to cleave host proteins particularly human immunoglobulins was tested. The ESPAg SLM from the $4^{\text {th }}$ day of culture were incubated with IgG subclasses 1 and 2 . Figure 4 shows that after 24 hours of treatment at $27{ }^{\circ} \mathrm{C}$ or $37^{\circ} \mathrm{C}$ in $50 \mathrm{mM}$ acetate buffer $\mathrm{pH} 4.5$ or $\mathrm{pH} 5.6$ a human $\mathrm{IgG}_{1}$ showed a partial cleavage of the heavy chain in three fragments of 33, 34 and $46 \mathrm{kDa}$ (Fig. 4a, lane 3 and 4), compared with the control of ESPAg SLM and IgG without digesting (Fig. 4a, lane 1 and 2). A human $\operatorname{IgG}_{2}$ treated in the same conditions produced heavy chain fragments of 29 and $36 \mathrm{kDa}$ (Fig. 4b, lane 9 to 12), compared with

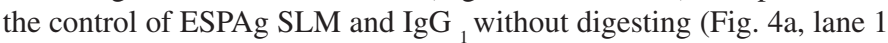
and Fig. 4b, lane 8).
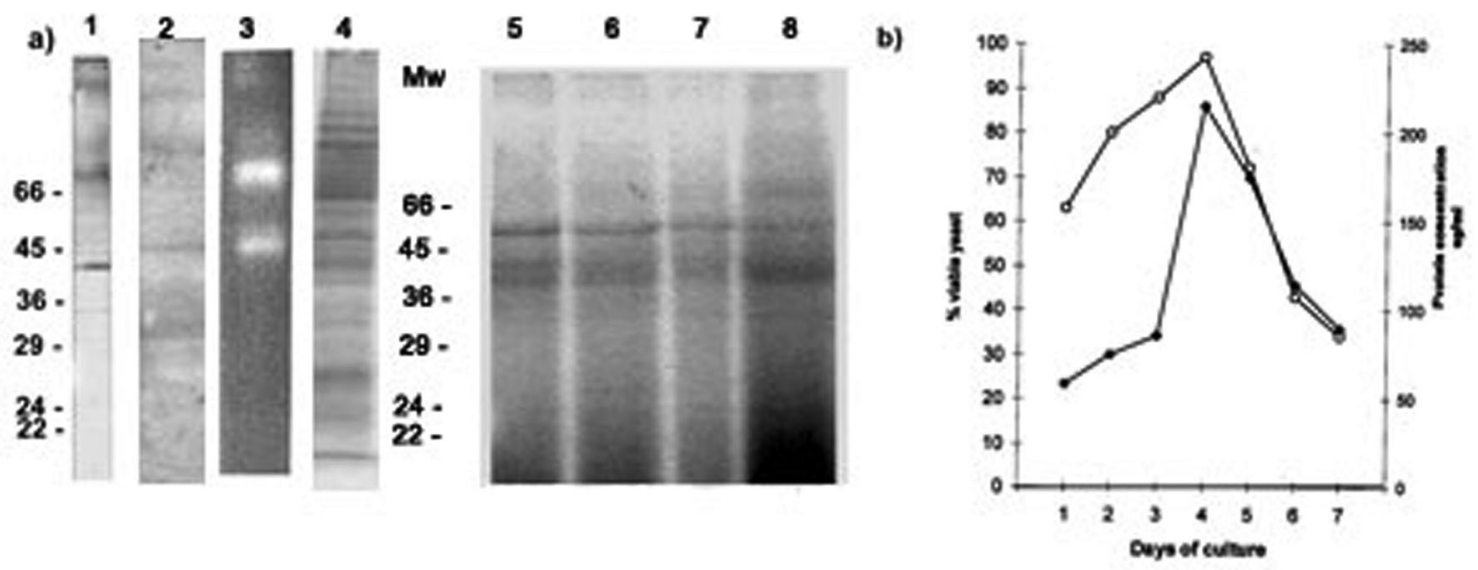

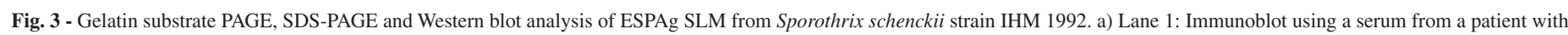

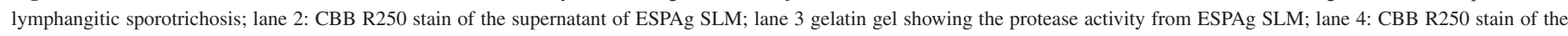
supernatant of sonicated Ss yeast (Som Ag); lanes 5 to 8: Ss ESPAg SLM from day 1 to day 4 of culture. 


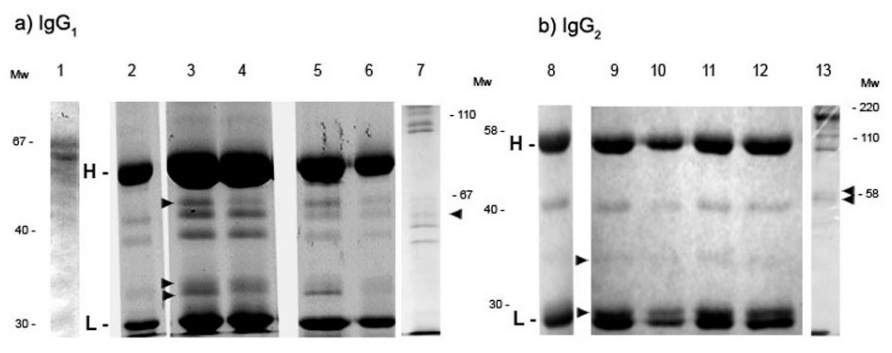

Fig. 4 - 12.5\% SDS-PAGE from the digestion of $\operatorname{IgG}_{1}$ (a) and $\operatorname{IgG}_{2}$ (b) by Sporothrix schenckii exoantigens. All samples were reduced with DTT prior to the run. Lane 1: ESPAg SLM control; Lane 2: $\operatorname{IgG}_{1}$ control undigested; Lanes 3 and 4: $\operatorname{IgG}_{1}+$ Ss ESPAg SLM incubated for $24 \mathrm{~h}$ at $\mathrm{pH} 4.5,27^{\circ} \mathrm{C}$ and $37^{\circ} \mathrm{C}$; Lanes 5 and $6: \operatorname{IgG}_{1}+\mathrm{Ss}$ ESPAg SLM incubated for $24 \mathrm{~h}$ at pH 5.6, $37^{\circ} \mathrm{C}$; Lane $7: \operatorname{IgG}_{1}+$ Ss ESPAg SLM incubated for $24 \mathrm{~h}$ at $\mathrm{pH} 5.6,37^{\circ} \mathrm{C}$, non reduced; Lane 8: $\mathrm{IgG}_{2}$ control undigested; Lanes 9 and $10: \mathrm{IgG}_{2}+$ Ss ESPAg SLM incubated for $24 \mathrm{~h}$ at $\mathrm{pH} 4.5,27^{\circ} \mathrm{C}$ and $37^{\circ} \mathrm{C}$; Lane 11: $\operatorname{IgG}_{2}+$ Ss ESPAg SLM incubated for $24 \mathrm{~h}$ at $\mathrm{pH} 5.6$, $37^{\circ} \mathrm{C}$; Lane 12: $\operatorname{IgG}_{2}+$ Ss ESPAg SLM incubated for $24 \mathrm{~h}$ at $\mathrm{pH} 7.2,37^{\circ} \mathrm{C}$; Lane $13: \mathrm{IgG}_{2}$ + Ss ESPAg SLM incubated $24 \mathrm{~h}$ at $\mathrm{pH} 5.6,37^{\circ} \mathrm{C}$, non reduced.

\section{DISCUSSION}

Although in recent years we have seen noticeable advances in the specific immune diagnosis of many human deep mycoses, it has not been the case for human sporotrichosis ${ }^{4,6,8,21}$.

In the present study we have stressed the importance of producing excretion-secretion products of viable yeast to be used as specific biological markers for the disease; and we have proposed a relatively easy methodology to obtain these antigenic preparations.

The whole system is based primarily in the transformation and maintenance of mycelial phase into a yeast phase. The transformation of Ss mycelial phase to pure yeast phase culture was difficult but proved to be feasible provided certain characteristics were rigorously kept such as the use of BHIGA without additives, $36.5^{\circ} \mathrm{C}$, pH 7.4 and a $5 \% \mathrm{CO}_{2}$ atmosphere. The transformation into pure yeast phase was achieved after at least twelve passages for most of the strains (Fig. 1). Once this stage was attained the maintenance of the culture with a sustained production of yeasts in enough quantities to perform several immune tests was routinely done (Fig. 2).

Contrary to other studies that have used mycelial phase or in the best of conditions mixed cultures of mycelia, conidia and yeasts with unknown viability $^{21,30}$; we have developed a system to quantify the percentage of yeast phase in any passage until we could label the culture pure in one of the species. In order to label the culture as pure yeast phase or $100 \%$ yeast phase we had to ascertain after examination in a hemocytometer that there were yeasts in all fields, we counted at least 500 cells and we could not see any conidia or mycelia. In this way we standardized all cultures to be compared and obtained reproducible results.

The second important consideration was in the change of the media or passages in solid phase as often as needed with special emphasis on cell viability. Only cultures with more than $95 \%$ of viable cells were used to produce ESPAgs (Fig. 1b). This cut-off assured us that only negligible amounts of somatic antigens would be present in the preparations, being the most important change the absence of cell wall antigens, i.e. complex high mannose oligosaccharide chains, probably responsible for the crossreactions with other fungi $i^{8,19,20,23}$.

Somatic antigens might not be the only source of contamination; in fact, the scrapping from the BHIGA had to be gentle to avoid taking culture media proved to have proteases and glycoproteins that could be mistaken as fungal contents in certain assays (data not shown). To prevent it, the scrapped yeasts from the fourth day of culture were also washed a quick few times in PBS before being used for producing the ESPAg. This last step was carried out overnight at $4{ }^{\circ} \mathrm{C}$ to maintain viability over $95 \%$. Thus, the methodology allowed us to obtain supernatants of the ESPAgs SLM with a protein concentration high enough to be used in different assays without further processing (Fig. 1b).

To perform double immunodiffusion tests in agar only viable yeasts (ESPAg LY and ESPAg SLM) were used. The newly formed antigens without somatic contaminants were produced while on the plates and proved to be a useful tool to achieve specificity as it could be seen when tested alongside Som Ag against the sera from patients with different mycoses (Fig. 2 III, a and b).

The sequential analysis of the secreted proteins in the first four days of the cultures showed differential expression of glycoproteins coincidental with antigenic changes and diverse protease activities.

The offering of different antigens to the immune system is accompanied by the production of new antibodies by the host; however, this qualitative and quantitative change is not followed by an effective clarification of the yeasts from tissues or circulation, and the infection typically proceeds to chronicity ${ }^{9,15}$.

The antigenic variation may pose a problem for the specific detection of Ss. Some of the cell surface antigenic determinants in both yeast and mycelial phase appear to be specific for $\mathrm{Ss}^{8}$; however, the crossreactions reported in other publications might be attributed to the use of sonicated yeasts and the subsequent detection of cell wall antigens like the monorhamnosyl rhamnomannans ${ }^{17,19}$. Here, we have demonstrated that by using viable cells producing only secreted Ags we could avoid most of the cross-reactions with other fungal infections.

The sera from patients carrying a cutaneous form of sporotrichosis could detect two major antigens of 70 and $40 \mathrm{kDa}$ in the ESPAgs SLM preparations. Immunodominant proteins of similar molecular weights were detected by SCOTT \& MUCHMORE ${ }^{28}$ in preparations of sonicated yeasts.

Also, the synthesis of more than one protease in yeasts has been previously reported for other fungi $i^{2,30,33}$. In our case we have detected in ESPAgs SLM at low pHs, at least two distinct protease activities that were characterized by fluorogenic substrates. They are in accordance with the findings by TSUOBI et al. ${ }^{31}$ obtained in yeast cultures containing some filamentous material.

The sequential variation of the proteolytic activities reported in Table 1 might help to explain the ability of the fungus to invade tissues of the host after the conidia were introduced through even a small trauma. HEMPEL \& GOODMAN ${ }^{14}$ have determined that 24 to 48 hours is the lapsed time between the conidia invasion and the transformation to 
DA ROSA, D.; GEZUELE, E.; CALEGARI, L. \& GOÑI, F. - Excretion-secretion products and proteases from live Sporothrix schenckii yeast phase. Immunological detection and cleavage of human IgG. Rev. Inst. Med. trop. S. Paulo, 51(1): 1-7, 2009.

Table 1

Specific peptidase activity of ESPAg SLM on different fluorogenic peptides performed at $37{ }^{\circ} \mathrm{C}$ in $50 \mathrm{mM}$ citrate $\mathrm{pH} 4.5$. The measurements are expressed as $\mu \mathrm{mols}$ of $\mathrm{Mec} / \mathrm{min} / \mathrm{mg}$. Each measurement is the average of at least three determinations

\begin{tabular}{ccc}
\hline \multicolumn{3}{c}{ ESPAg SLM } \\
\hline 2 days & Fluorogenic Peptide & 4 days \\
\hline PBS & & PBS \\
103 & N-Boc-Val- Leu- Lys. AMC & 101 \\
649 & NCBZ-Phe- Arg. AMC & 97 \\
232 & N-Succinyl-Leu- Leu- Val- Tyr.AMC & 56 \\
41 & N-Succinyl-Ala- Ala- Pro- Phe. AMC & 498 \\
84 & N-Succinyl-Gly-Pro-Leu-Gly-Pro. AMC & 408 \\
49 & NCBZ-Gly- Gly- Arg. AMC & 105 \\
\hline
\end{tabular}

yeast in the host. This lapsed time is coincidental with the expression of proteolytic activity observed at day two in cultures.

We also demonstrated that the proteases present in the ESPAg SLM were able to interact with immunoglobulins at a $\mathrm{pH}$ and temperature similar to the ones observed in inflammatory processes, cleaving both $\mathrm{IgG}_{1}$ and $\mathrm{IgG}_{2}$ in the microenvironment of the live yeasts, and producing polypeptide fragments consistent in molecular weight with Fab and Fc (Fig. 4). It will be worth to further study this process that might be of importance to explain interference by the fungi of the humoral immune response of the host.

In sum, the production of pure viable yeast phase from Sporothrix schenckii might help to produce very specific antigenic products and eventual detection systems to be used in the proteomics of the fungal invasion and survival.

\section{RESUMO}

\section{Produtos da excreção-secreção e proteases da fase leveduriforme do Sporothrix schenckii. Detecção imunológica e clivagem de IgG humana}

As preparações antigênicas de Sporothrix schenckii provêm geralmente de cultivos mistos de leveduras e micélios e apresentam reações cruzadas com outras micoses profundas. Foi padronizada a obtenção da fase leveduriforme pura, com alto índice de células viáveis, o que permite, por sua vez, obter produtos específicos da excreção-secreção sem contaminantes somáticos. Estes produtos da excreção-secreção são altamente imunogênicos, e não apresentam reações cruzadas visíveis em dupla difusão e sem Western blot. O preparado antigênico consiste principalmente em proteínas com peso molecular entre 40 e $70 \mathrm{kDa}$, sendo que algumas apresentam atividade proteolítica em meios levemente ácidos.

Foi observada atividade do tipo catepsina em produtos da excreçãosecreção obtidos a partir de leveduras de dois dias de cultivo, e atividade do tipo quimiotripsina aos quatro dias de cultivo, consistente com a mudança de concentração de proteínas secretadas. As proteases puderam clivar diferentes subclasses de IgG humanas, o que sugere uma produção seqüencial de antígenos e moléculas que podem interagir com a resposta imune do hospedeiro.

\section{REFERENCES}

1. ACOSTA, D.; GOÑI, F. \& CARMONA, C. - Characterization and partial purification of a leucine aminopeptidase from Fasciola hepatica. J. Parasit., 84: 1-7, 1998

2. ASAHI, M.; LINDQUIST, R.; FUKUYAMA, K. et al. - Purification and characterization of major extracellular proteinases from Trichophytom rubrum. Biochem. J., 232: 139-144, 1985

3. BERASAIN, P.; CARMONA, C.; FRANGIONE, B.; DALTON, J. P. \& GOÑI, F. Fasciola hepatica: parasite-secreted proteinases degrade all human IgG subclasses: determination of the specific cleavage sites and identification of the immunoglobulin fragments produced. Exp. Parasit., 94: 99-110, 2000.

4. BERnARDES-ENGEMANn, A.R.; COSTA, R.C.; MIGUENS, B.R. et al. Development of an enzyme-linked immunoabsorbent assay for the serodiagnosis of several clinical forms of sporotrichosis. Med. Mycol., 43: 487- 493, 2005.

5. CALICH, V.L.; PURCHIO, A. \& PAULA, C.R. - A new fluorescent viability test for fungi cells. Mycopathologia (Den Haag), 66: 175-177, 1979.

6. CAMARGO, Z.P.; BERZAGHI, R.; AMARAL, C.C. \& SILVA S.H. - Simplified method for producing Paracoccidioides brasiliensis exoantigens for use in immunodiffusion tests. Med. Mycol., 41: 539-542, 2003.

7. CARLOS, I.Z.; SGARBI, D.B. \& PLACERES, M.C. - Host organism defense by a peptide-polysaccharide extracted from the fungus Sporothrix schenckii. Mycopathologia (Den Haag), 144: 9-14, 1998/1999.

8. CASTILLO, M.C.; TAPIA, F.J. \& ARCINIEGAS, E. - Ultrastructural localization of specific surface antigens in the dimorphic fungus Sporothrix schenkii. J. Med. vet. Mycol., 28: 91-94, 1990

9. CONTI DIAZ, I.A. - Epidemiology of sporotrichosis in Latin America. Mycopathologia (Den Haag), 108: 113-116, 1989.

10. DALTON, J.P. \& HEFFERNAN, M. - Thiol proteases released in vitro by Fasciola hepatica. Mol. Biochem. Parasitol., 35: 161-166, 1989.

11. De AlbornOZ, M.B.; VILLANUEVA, E. \& DE TORRES, E.D. - Application of immunoprecipitation techniques to the diagnosis of cutaneous and extracutaneous forms of sporotrichosis. Mycopathologia (Den Haag), 85: 177-183, 1984.

12. DEEPE, G.S.; GIBBONS, R.; BRUNNER, G.D. \& GOMEZ, F.J. - A protective domain of heat-shock protein 60 from Histoplasma capsulatum. J. infect. Dis., 174: 828-834, 1996 .

13. GOIHMAN-YAHR, M.; PINE, L. \& ALBORNOZ, M.C. et al. - Studies on plating efficiency and estimation of viability of suspensions of Paracoccidioides brasiliensis yeast cells. Mycopathologia (Den Haag), 71: 73-83, 1980.

14. HEMPEL, H. \& GOODMAN, N.L. - Rapid conversion of Histoplasma capsulatum, Blastomyces dermatitidis and Sporothrix schenckii in tissue culture. J. clin. Microbiol., 1: 420-424, 1975.

15. KAUFFMAN, C.A. - Sporotrichosis. Clin. infect. Dis., 29: 231-236, 1999.

16. LAEMMLI, U.K. - Cleavage of structural proteins during the assembly of the head of bacteriophage T4. Nature, 227: 680-685, 1970.

17. LIMA, O.C. \& BEZERRA, L.M. - Identification of a concanavalin A-binding antigen of the cell surface of Sporothrix schenckii. J. med. vet. Mycol., 35: 167-172, 1997. 

of human IgG. Rev. Inst. Med. trop. S. Paulo, 51(1): 1-7, 2009.

18. LIMA, O.C.; FIGUEIREDO, C.C.; PEREIRA, B.A. et al. - Adhesion of the human pathogen Sporothrix schenckii to several extracellular matrix proteins. Braz. J. med. biol. Res., 32: 651-657, 1999.

19. LLOYD, K.O. \& BITOON, M.A. - Isolation and purification of a peptidorhamnomannan from the yeast form of Sporothrix schenckii. Structural and immunochemical studies. J. Immunol., 107: 663-671, 1971.

20. LLOYD, K.O. \& TRAVASSOS, L.R. - Immunochemical studies on L-rhamno-Dmannans of Sporothrix schenckii and related fungi by use of rabbit and human antisera. Carbohydr. Res., 40: 89-97, 1975.

21. MENDOZA, M.; DIAZ, A.M.; HUNG, M.B. et al. - Production of culture filtrates of Sporothrix schenckii in diverse culture media. Med. Mycol., 40: 447-454, 2002.

22. OUCHTERLONY, O. - Antigen-antibody reactions in gels. Acta path. microbiol. scand., 26: 507-515, 1949.

23. POLONELLI, L. \& MORACE, G. - Exoantigen studies of Sporothrix schenckii, Ceratocystis minor, and Graphium penicillioides cultures. J. clin. Microbiol., 15: $362-365,1982$.

24. RASKA, M.; ZEMANOVA, E.; KAFKOVA, L. et al. - Isolation and characterization of an immunogenic fragment of heat shock protein 60 from Trichophyton mentagrophytes. Mycoses, 47: 482-490, 2004.

25 REDINBAUGH, M.G. \& TURLEY, R.B. - Adaptation of the bicinchoninic acid protein assay for use with microtiter plates and sucrose gradient fractions. Analyt. Biochem. 153: $267-271,1986$.
26. REED, K.D.; MOORE, F.M.; GEIGER, G.E. \& STEMPER, M.E. - Zoonotic transmission of sporotrichosis: case report and review. Clin. infect. Dis., 16: 384 $387,1993$.

27. SCHUBACH, A.O.; SCHUBACH, T.M. \& BARROS, M.B. - Epidemic of cattransmitted sporotrichosis. New. Engl. J. Med., 353: 1185-1186, 2005.

28. SCOTT, E.N. \& MUCHMORE, H.G. - Immunoblot analysis of antibody responses to Sporothrix schenckii. J. clin. Microbiol., 27: 300-304, 1989.

29. TOWBIN, H.; STAEHELIN, T. \& GORDON, J. - Electrophoretic transfer of proteins from polyacrilamide gels to nitrocellulose sheets: procedures and some applications. Proc. nat. Acad. Sci. (Wash.), 76: 4350-4354, 1979.

30. TSUBOI, R.; SANADA, T.; TAKAMORI, K. \& OGAWA, H. - Isolation and properties of extracellular proteinases from Sporothrix schenckii. J. Bact., 169: 4104-4109, 1987.

31. TSUOBI, R.; KURITA, Y.; NEGI, M. \& OGAWA, H. - A specific inhibitor of keratinolytic proteinase from Candida albicans could inhibit the cell growth of $C$. albicans. J. invest. Derm., 85: 438-440, 1985.

32. VAITUKAITIS, J.; ROBBINS, J.B.; NIESCHLAG, E. \& ROSS, G.T. - A method for producing specific antisera with small doses of immunogen. J. clin. Endrocr. 33: 988-991, 1971.

33. YU, R.J.; HARMON, S.R.; GRAPPEL, S.F. \& BLANK, F. - Two cell-bound keratinases of Trichophyton mentagrophytes. J. invest. Derm., 56: 27-32, 1971.

Received: 26 November 2007

Accepted: 24 November 2008 